\title{
PROBLEM INTERNOWANIA 2. DYWIZJI STRZELCÓW PIESZYCH W POLSKO-SZWAJCARSKICH STOSUNKACH DYPLOMATYCZNYCH W LATACH 1940-1941
}

\section{Paweł Duber}

\author{
ABSTRACT \\ THE INTERNMENT OF THE SECOND RIFLE DIVISION \\ IN THE POLISH-SWISS DIPLOMATIC RELATIONS 1940-1941
}

This article concerns the problem of mutual diplomatic relations between Switzerland and Polish authorities in exile after the collapse of France in June 1940. During this period of time the fate of the Polish division interned was unstable, due to the position of the Swiss Federal Political Department. Its chief Marcel Pilet Golaz intended to send the Poles back to France and tried to get the German approval for his purpose. It was in blatant contradiction to the intention of Polish commander-in-chief Władysław Sikorski and his endeavours to preserve the Polish division as a military unit able to continue the fight against the Third Reich. The tactic proposed by Polish envoy in Bern Aleksander Ładoś was more flexible. He advised his superiors to release from service the persons living in France before the outbreak of war in order to maintain the rest of the Polish soldiers as an efficient combat unit. Despite the formal agreement from January 1941, combined with the German reluctance to receive Polish soldiers, the chief of Helvetian diplomacy didn't give up his plans until the German's assault on the Soviet Union in June 1941.

Key words: diplomatic relations, Poland, Switzerland, internment, Second World War, Second Rifle Division.

Słowa kluczowe: stosunki dyplomatyczne, Polska, Szwajcaria, internowanie, II wojna światowa, 2. Dywizja Strzelców Pieszych.

W czerwcu 1940 roku granicę francusko-szwajcarską przekroczył 45. Korpus Armii Francuskiej i zgodnie z przepisami prawa międzynarodowego został internowany ${ }^{1}$. Fakt ten od samego początku stanowił dla władz federalnych w Bernie

1 Szerzej na ten temat zob. M. Matyja, Internowanie polskiej 2. Dywizji Strzelców Pieszych w Szwajcarii w latach 1940-1945 na podstawie V konwencji haskiej z 1907 roku, Brzezia Łąka 2013, s. $137-150$.

Adres do korespondencji: pduber@o2.pl 
nie lada problem. Utrzymanie kilkudziesięciu tysięcy żołnierzy w obliczu trwającego konfliktu zbrojnego na kontynencie europejskim stanowiło niewątpliwie duże wyzwanie z punktu widzenia aprowizacji, nie mówiąc już o konieczności przeznaczenia poważnych sił do działań o charakterze wartowniczym. A wszystko wskazywało przecież na to, że wojna potrwa jeszcze długo, być może nawet kilka najbliższych lat. Szwajcarzy od samego początku szukali więc możliwości pozbycia się nieproszonych gości ze swojego terytorium, co nie było wbrew pozorom zadaniem łatwym, biorąc pod uwagę fakt, że pomiędzy Francją a Niemcami doszło zaledwie do zawarcia rozejmu. Tymczasem jedynie podpisanie formalnego traktatu pokojowego umożliwiało państwu neutralnemu odesłanie internowanych żołnierzy do ich ojczyzny. A przynajmniej tak wyglądał ten problem z punktu widzenia teorii prawa międzynarodowego, co, jak często w takich wypadkach bywa, niekoniecznie musiało znaleźć swoje odzwierciedlenie w praktyce.

Wkrótce okazało się bowiem, że Szwajcarzy postanowili jednak podjąć w tej sprawie bezpośrednie rozmowy z przedstawicielami Francji i Niemiec, a stawką był oczywiście powrót do domu żołnierzy 45. Korpusu. Problem polegał jednak na tym, że w ramach tej jednostki walczyła również 2. Dywizja Strzelców Pieszych (2. DSP), będąca częścią Polskich Sił Zbrojnych, co zostało usankcjonowane specjalną umową polsko-francuską zawartą kilka miesięcy wcześniej pomiędzy rządami obu państw². Pomimo to strona polska nie została do tych rozmów dopuszczona, choć od ich wyniku zależał przecież los tysięcy obywateli II Rzeczpospolitej walczących w obronie Francji. Ostatecznie w styczniu 1941 roku udało się doprowadzić do porozumienia przewidującego powrót francuskich żołnierzy do domu, podczas gdy sprzęt bojowy (z wyjątkiem koni), w tym także ten należący do 2. DSP, miał zostać oddany bezpośrednio w ręce Niemców. Szwajcarzy osiągnęli niewątpliwie sukces, był on jednak połowiczny, z warunków porozumienia wyłączono bowiem Polaków, którzy mieli pozostać na miejscu ${ }^{3}$.

Poseł RP w Bernie Aleksander Ładoś podejmował oczywiście próby uzyskania wpływu na toczące się rozmowy. Nie został jednak do nich formalnie dopuszczony i mógł jedynie próbować oddziaływać nieoficjalnie na stanowisko strony szwajcarskiej. Sprawę dodatkowo utrudniał fakt, że jego koncepcja rozwiązania problemu internowanej 2. DSP nie spotkała się z uznaniem Naczelnego Wodza gen. Władysława Sikorskiego. W dotychczasowej historiografii przechodzi się w zasadzie nad tymi kontrowersjami do porządku dziennego, nie przywiązując do nich większej wagi, podczas gdy miały one dosyć istotne znaczenie. Dominuje również opinia, że styczniowe porozumienia oznaczały zakończenie zabiegów o pozostanie 2. DSP

2 Więcej zob.: J. Zuziak, Wojsko Polskie we Francji 1939-1940. Organizacja i działania bojowe, Warszawa 2013, s. 61-63; T. Wyrwa, Odbudowa władz Rzeczypospolitej w Paryżu i Angers wrzesień 1939 - czerwiec 1940 [w:] Władze RP na obczyźnie podczas II wojny światowej 1939-1945, red. Z. Błażyński, Londyn 1994, s. 62.

3 E. Bonjour, Histoire de la neutralité suisse pendant la Seconde Guerre mondiale, t. VI, Neuchâtel 1971, s. 67-72. 
w Szwajcarii ${ }^{4}$. Tymczasem ówczesna sytuacja była znacznie bardziej złożona, niż może się to pozornie wydawać, a w okresie pierwszego półrocza 1941 roku relacje Poselstwa RP ze szwajcarskim Federalnym Departamentem Politycznym (FDP) nie układały się najlepiej. Na czym polegała istota tego konfliktu i czego tak naprawdę on dotyczył? Szczegółowa analiza wielu nieznanych dotąd dokumentów przechowywanych w archiwach polskich i szwajcarskich pozwala niewątpliwie ukazać problem internowania polskiej jednostki oraz stosunek władz federalnych do tego zagadnienia w nieco odmiennym świetle niż dotychczas. Warto także zastanowić się nad czynnikami, które zaważyły ostatecznie na zmianie stanowiska FDP do problemu pobytu polskiej dywizji na terenie Szwajcarii. Cezury chronologiczne artykułu obejmują z jednej strony początek wielostronnych negocjacji na temat dalszych losów dywizji, z drugiej natomiast ostateczną stabilizację jej położenia latem 1941 roku.

2. DSP stanowiła formalnie integralną część Polskich Sił Zbrojnych podległych rządowi RP na uchodźstwie i takie też było oficjalne stanowisko gen. Sikorskiego, wyrażone przez niego w telegramie przesłanym do Berna trzy dni po przekroczeniu przez nią granicy francusko-szwajcarskiej. Początkowo Naczelny Wódz brał pod uwagę możliwość zwolnienia obywateli polskich od lat zamieszkałych we Francji z obowiązku dalszej służby wojskowej, umożliwiając im tym samym powrót do domu ${ }^{5}$. Władzom szwajcarskim należało jednak udowodnić odrębny charakter Polskich Sił Zbrojnych oraz podkreślić, że pomimo francusko-niemieckiego rozejmu z 22 czerwca Polska w dalszym ciągu kontynuuje walkę u boku Wielkiej Brytanii. Co więcej, Ładoś już wtedy obawiał się, że dywizja jako całość może zostać odesłana do Francji. W związku z tym problemem dwa dni później do Berna dotarła kolejna depesza zawierająca fragmenty polsko-francuskiej umowy wojskowej ${ }^{6}$, co 1 lipca umożliwiło sekretarzowi Poselstwa RP w Bernie Stefanowi Ryniewiczowi złożenie w FDP specjalnej noty zawierającej między innymi odpowiednie artykuły polsko-francuskiej umowy wojskowej z 4 stycznia 1940 roku. Dokument ten nie pozostawiał żadnych wątpliwości co do prawnego statutu internowanej dywizji ${ }^{7}$. Przez okres

4 W celu przekonania się o tym wystarczy sięgnąć do jednej z najbardziej klasycznych prac poświęconych problemowi internowania 2. DSP. Zob. J. Smoliński, 2. Dywizja Strzelców Pieszych (Francja-Szwajcaria), Warszawa 1992, s. 73-76.

5 Telegram z Londynu nr 8 z 23.6.1940, AAN, Poselstwo RP w Bernie, sygn. 318. Podobne decyzje zostały wówczas podjęte $\mathrm{w}$ odniesieniu do żołnierzy polskich internowanych na terenie Rumunii, co miało związek z poważnymi trudnościami, na jakie natrafiono $\mathrm{w}$ związku $\mathrm{z}$ wydarzeniami na froncie zachodnim. Zob. T. Dubicki, Wojsko Polskie w Rumunii w latach 1939-1941, Warszawa 1994, s. 244 245.

Telegram do Londynu nr 15 z 25.6.1940, AAN, Poselstwo RP w Bernie, sygn. 318; Telegram z Londynu nr 10 z 27.6.1940, AAN, Poselstwo RP w Bernie, sygn. 318. Ładoś wspominał po latach, że wkrótce po internowaniu 2. DSP do Poselstwa RP zaczęły docierać informacje mogące świadczyć o odmiennym postrzeganiu statusu prawnego polskiej jednostki przez władze szwajcarskie. Pierwszym niepokojącym sygnałem miały być problemy ze złożeniem w FDP oficjalnego dokumentu, w którym rząd RP deklarował swoją gotowość do wzięcia na siebie wszelkich kosztów związanych z pobytem polskich żołnierzy na terytorium Szwajcarii. Zob. A. Ładoś, Wspomnienia, t. III, Centralne Archiwum Wojskowe (dalej CAW), sygn. IX. 1. 2. 20, s. 42-43.

7 Notice concernant les démarches polonaise et britanique au sujet des frais d'internement des militaires polonaise [24.09.1948], AFS, E 2001D, 1000/1553/320. 
najbliższych kilku miesięcy sprawa ta pozostawała jednak formalnie w zawieszeniu, aż do później jesieni, gdy do Poselstwa RP zaczęły docierać pierwsze sygnały o możliwości odesłania internowanych żołnierzy 45. Korpusu do Francji. Fakt ten nie mógł oczywiście pozostać bez wpływu na sytuację 2. DSP.

Ładoś doskonale zdawał sobie $\mathrm{z}$ tego faktu sprawę. Zapewne domyślał się również, że Szwajcarzy niekoniecznie podzielają stanowisko rządu polskiego w sprawie statusu prawnego polskiej jednostki, przewidywał w związku z tym konieczność przeprowadzenia $\mathrm{z}$ nimi $\mathrm{w}$ tej sprawie formalnych negocjacji. Wiedział, że nie będą one łatwe, w związku z tym postanowił odwołać się do treści wspomnianej wcześniej depeszy Sikorskiego z 23 czerwca, chcąc wykorzystać zawarte w niej propozycje w celu uzyskania dogodnej podstawy negocjacyjnej. Znając dobrze nastroje panujące wśród internowanych, zgadzał się z koniecznością powrotu do Francji żołnierzy wywodzących się z przedwojennej emigracji zarobkowej, co umożliwiłoby pozostałym pozostanie na miejscu. Ze swojej strony zasugerował jedynie Naczelnemu Wodzowi, aby zezwolić na opuszczenie Szwajcarii tylko tym osobom, które po drugiej stronie granicy posiadały rodziny, środki utrzymania, a co najważniejsze - wyrażały chęć podobnego wyjazdu ${ }^{8}$. Początkowo Londyn nie zają jednak w tej sprawie określonego stanowiska, nie zareagował również na niepokojące doniesienia posła o pogarszającej się atmosferze w obozach, a także coraz bardziej niepewnym stanowisku władz federalnych $w$ kwestii statusu prawnego 2. DSP9. Sytuacja $z$ dnia na dzień stawała się coraz groźniejsza, w związku z czym trzy dni później Ładoś po raz kolejny wysłał do Londynu dosyć alarmujące informacje o niekorzystnym dla Polski przebiegu szwajcarsko-francusko-niemieckich rozmów oraz stale zwiększającej się presji, jakiej poddawane było Berno, co mogło według niego doprowadzić nawet do wydania hitlerowcom polskich żołnierzy ${ }^{10}$. Sprawa komplikowała się dodatkowo z powodu postawy samego Sikorskiego, który zmienił swoje poprzednie stanowisko, podkreślając obecnie konieczność utrzymania 2. DSP w niezmienionej formie jako jednolitej, zwartej jednostki, co wykluczało oczywiście możliwość powrotu części internowanych do Francji. Informacje te dotarły do polskiego posła kanałami wojskowymi, a więc niejako okrężną drogą ${ }^{11}$, co trudno raczej uznać za sytuację normalną. Stawiało to Ładosia $\mathrm{w}$ dosyć trudnym położeniu, uważał bowiem takie stanowisko za niebezpieczne, ponieważ przekreślało ono jakąkolwiek możliwość osiągnięcia kompromisu ze stroną szwajcarską. Nie pozostało mu więc nic innego jak spróbować przekonać Naczelnego Wodza do zmiany zdania. W tym celu zaproponował mu, jak to określił, „przenieść całą sprawę na grunt wyłącznie humanitarny” i podjąć próbę włączenia się do prowadzonych rozmów w celu podpisania trójstronnego,

8 Telegram do Londynu nr 160 z dn. 19.11.1940, AAN, Poselstwo RP w Bernie, sygn. 318.

9 Depesza do Londynu nr 165 z dn. 3.12.1940, AAN, Poselstwo RP w Bernie, sygn. 318.

10 Telegram do Londynu nr 174 z 6.12.1940, AAN, Poselstwo RP w Bernie, sygn. 318.

11 Ibidem. Stanowisko Sikorskiego w tej sprawie było znane w dowództwie 2. DSP już 24 listopada. Zob. Odpis depeszy Naczelnego Wodza nr 2434 do ppłk Bronisława Noëla z 23 listopada 1940 r., CAW, 2DSP, II. 50. 197, k. 56. 
polsko-francusko-szwajcarskiego układu umożliwiającego członkom przedwojennej emigracji powrót do domu ${ }^{12}$.

Nawet ta depesza nie doprowadziła do bardziej zdecydowanej reakcji ze strony Londynu, a czas przecież naglił. Polski poseł postanowił w związku z tym działać $\mathrm{w}$ tej sprawie na własną rękę. Przede wszystkim przeprowadził poufnie rozmowy zarówno z przedstawicielami władz szwajcarskich, jak i z ambasadorem francuskim, proponując, jak można się domyślać, podpisanie wspomnianego wcześniej trójstronnego porozumienia w celu umożliwienia żołnierzom wywodzącym się z przedwojennej emigracji zarobkowej powrót do rodzin pozostawionych we Francji. Ładoś nie wspomniał o szczegółach tych negocjacji w raportach przesyłanych do Londynu, można się jednak domyślać, że z powodu braku jakichkolwiek instrukcji postanowił działać w myśl przedstawionych przez siebie propozycji. Niespodziewanie okazało się jednak, że sprawa być może sama rozwiąże się po myśli posła, sprzeciw wobec powrotu Polaków do Francji wyrazili bowiem... Niemcy. Oczywiście były to jedynie niepotwierdzone informacje i wszystko mogło się jeszcze wydarzyć, tym bardziej że stanowisko strony szwajcarskiej było w dalszym ciągu nieustępliwe. Póki co Ładoś uzyskał jedynie deklarację, że ,,sprawa Polaków z Polski będzie traktowana z uwzględnieniem niemożności ich wyjazdu ani do Francji ani do okupacji" "13. Tego samego dnia, gdy polski poseł wysyłał raport z powyższymi informacjami do Londynu, do Berna dotarły dwie depesze $\mathrm{z}$ instrukcjami w tej sprawie, przerywając wcześniejsze milczenie. Przede wszystkim minister spraw zagranicznych August Zaleski nakazał polskiemu posłowi zachować nieustępliwą postawę, miał się on także powołać na przepisy konwencji haskich oraz polsko-francuską umowę ze stycznia 1940 roku. Odmienna interpretacja statutu polskich żołnierzy została określona jako próba „naruszenia suwerenności polskiej”"14.

Stanowisko to było jak najbardziej słuszne z prawnego punktu widzenia, problem polegał jednak na tym, że w obecnej sytuacji nie miało to już większego realnego znaczenia. Władze szwajcarskie interpretowały bowiem istniejące przepisy, kierując się wyłącznie własnymi interesami. Ładoś zwrócił w związku z tym uwagę na bezcelowość posługiwania się podobną argumentacją, ponieważ FDP nie czuł się w żaden sposób związany postanowieniami polsko-francuskiej umowy wojskowej określanej przez dyrektora Wydziału Spraw Zagranicznych Pierre'a Bonnę jako res inter alios acta $^{15}$. Podobnie myślał szef helweckiej dyplomacji Marcel Pilet-Golaz, który w rozmowach prowadzonych z Francuzami i Niemcami nie ukrywał, że jego zdaniem 45 . Korpus powinien być traktowany jako całość, bez względu na narodowość

12 Telegram do Londynu nr 174 z $6.12 .1940 \ldots$

13 Telegram do Londynu nr 178 z 12.12.1940, AAN, Poselstwo RP w Bernie, sygn. 318.

14 Depesza z Londynu nr 134 z dn. 12.12.1940, AAN, Poselstwo RP w Bernie, sygn. 318; Depesza z Londynu nr 135 z 12.12.1940, AAN, Poselstwo RP w Bernie, sygn. 318. Natomiast trzy dni później Sikorski formalnie zdezawuował wcześniejsze propozycje Ładosia i nakazał mu złożenie energicznego protestu w związku z postawą władz szwajcarskich. Zob. Depesza z Londynu nr 140 z dn. 15.12.1940, AAN, Poselstwo RP w Bernie, sygn. 318.

15 Depesza do Londynu nr 179 z dn. 13.12.1940, AAN, Poselstwo RP w Bernie, sygn. 318. 
wchodzących w jego skład żołnierzy ${ }^{16}$. Ciekawe światło na motywy, jakimi kierowały się wówczas władze szwajcarskie, rzuca treść interesującego dokumentu dotyczącego kosztów internowania polskiej dywizji. Co prawda został on sporządzony już po zakończeniu działań wojennych w Europie, przeznaczony był jednak do użytku wewnętrznego, można więc przyjąć, iż jego zawartość w dużej mierze oddaje wcześniejszy o ponad cztery lata sposób myślenia kierownictwa FDP. Okazuje się, że w ocenie kierownictwa helweckiej dyplomacji ówczesna sytuacja geopolityczna stawiała pod dużym znakiem zapytania samą możliwość restytucji w przyszłości niepodległego państwa polskiego ${ }^{17}$. Władze szwajcarskie obawiały się więc, że po zakończeniu wojny o żołnierzy 2. DSP nie będzie miał się kto upomnieć.

W tej sytuacji nieustępliwe stanowisko władz polskich w Londynie niewiele już mogło zmienić, ponieważ dalszy los dywizji miał się rozstrzygnąć bez udziału polskich dyplomatów. W korespondencji z Londynem w dalszym ciągu powracał jednak problem nastrojów panujących w obozach internowania. W jednej ze swoich depesz Zaleski wezwał Ładosia do podjęcia energicznych działań na rzecz poprawy sytuacji i skłonienia polskich żołnierzy do porzucenia myśli o wyjeździe do Francji ${ }^{18}$. O ile wierzyć wspomnieniom polskiego posła, on sam od samego początku przykładał dużą wagę do utrzymywania z nimi bliskiego kontaktu ${ }^{19}$. Od dawna obserwował więc narastające niezadowolenie, na co istotny wpływ miały również braki w zaopatrzeniu, szczególnie w obliczu zbliżającej się zimy. Ładoś od dłuższego czasu zwracał się bezskutecznie o udzielenie pomocy materialnej przeznaczonej dla polskich żołnierzy ${ }^{20}$. Brak jakiejkolwiek reakcji stawiał go niewątpliwie w trudnym położeniu. W jaki sposób miał bowiem wpłynąć na postawę internowanych w celu przekonania ich do dalszego trwania na posterunku i rezygnacji z myśli o powrocie do rodzin pozostawionych we Francji? Była to niewątpliwie główna przyczyna konfliktu, który poróżnił Ładosia nie tylko z gen. Sikorskim, lecz także z dowódcą 2. DSP gen. Bronisławem Prugarem-Ketlingiem ${ }^{21}$. W połowie grudnia napięcie osiągnęło najwyraźniej

16 Opinia ta opierała się na następującym rozumowaniu: duża część żołnierzy polskich walczących w ramach 2. DSP mieszkała przed wojną we Francji, byli także zaopatrzeni we francuski sprzęt bojowy oraz walczyli pod francuską komendą, należało więc ich traktować jak żołnierzy francuskich. Zob. E. Bonjour, Histoire..., s. 72-73. Por. P. Stauffer, Polacy - Żydzi - Szwajcarzy, Warszawa 2008, s. 126. Co ciekawe, Ładoś w swoich wspomnieniach bronił postawy zajętej w tej spawie przez szefa helweckiej dyplomacji, podkreślając, jak wielkie wrażenie wywarła na nim klęska Francji. Przy okazji nie krył również swojej sympatii do Pilet-Golaza. Zob. A. Ład oś, Wspomnienia, t. III, s. 5-6, 45-47.

17 Notice du 12 mai 1945, AFS, E2001D, 1000/1553/320. Natomiast za kuriozalne należy uznać inne argumenty zawarte $\mathrm{w}$ tym dokumencie, zgodnie $\mathrm{z}$ którymi postawa władz szwajcarskich uchroniła polskich żołnierzy przed ich wysłaniem do okupowanej Polski, czemu rzekomo Niemcy mieli się nie sprzeciwiać.

18 Depesza z Londynu nr 145 z 18.12.1940, AAN, Poselstwo RP w Bernie, sygn. 318.

19 A. Ładoś, Wspomnienia, t. III, s. 34-36.

20 Depesza do Londynu nr 104 z 7.-9.9.1940, AAN, Poselstwo RP w Bernie, sygn. 318; Depesza do Londynu nr 70 z 21.9.1940, AAN, Poselstwo RP w Bernie, sygn. 318; Depesza do Londynu nr 153 z dn. 5-8.11.1940, AAN, Poselstwo RP w Bernie, sygn. 318; Depesza do Londynu nr 165 z dn. 3.12.1940, AAN, Poselstwo RP w Bernie, sygn. 318.

${ }_{21}$ Miał on nawet wydać specjalny rozkaz, zabraniając swoim żołnierzom powrotu do Francji pod groźbą surowych sankcji, co nie mogło raczej przyczynić się do uspokojenia sytuacji. Zob. A. Ładoś, Wspomnienia, t. III, s. 41-44, 48-52. 
punkt kulminacyjny, o czym świadczy treść depeszy przesłanej przez Poselstwo RP do Londynu. Zaczynała się ona od następujących słów:

Odmowa pomocy finansowej dla II Dywizji stoi w rażącej sprzeczności z żądaniem utrzymaniem (sic!) jej zwartości i całości. Apelując do żołnierzy - emigrantów, aby nie skorzystali z ewentualnej możliwości powrotu do rodzin i warsztatów pracy we Francji, oraz żądając od reszty wojska, aby nie zwracała uwagi na mnożące się pogłoski o wydaniu ich Niemcom i nie patrzyła na wyjazd do Francji jako jedyne „okno na świat” - nie można równocześnie pozostawiać żołnierzy bez butów, bez płaszczy i mundurów, oraz wstrzymywać tej skromnej pomocy, której dotąd udzielało Poselstwo (sic!) $)^{22}$.

Trudno odmówić Ładosiowi racji, stanowisko polskiego rządu w sprawie przyszłości 2. DSP było bowiem nacechowane sprzecznościami i brakiem konsekwencji. W Londynie nie zdawano sobie najwyraźniej sprawy z powagi sytuacji. Dopiero w połowie grudnia zaczęło to powoli ulegać zmianie. Zwrócono się także o pomoc do Brytyjczyków, o czym Zaleski poinformował Ładosia ${ }^{23}$. Starania te zostały dosyć szybko uwieńczone sukcesem ${ }^{24}$, czemu trudno się dziwić, biorąc pod uwagę fakt, iż od dawna interesowali się oni losem polskiej dywizji, jeszcze w lipcu oferując Szwajcarom gotowość do udzielenia im określonego wsparcia finansowego. Postanowili więc interweniować także i tym razem, obawiając się wydania polskich żołnierzy w ręce Niemców ${ }^{25}$. Poparcie udzielone przez sojusznika miało z pewnością swoje określone znaczenie, warto bowiem pamiętać, że Szwajcaria, otoczona ze wszystkich stron przez państwa Osi, musiała zabiegać o względy Londynu z uwagi na konieczność importowania stamtąd wielu towarów o żywotnym znaczeniu z punktu widzenia potrzeb jej własnej gospodarki ${ }^{26}$. W tym przypadku należy jednak wątpić, czy wywarło to jakiś realny wpływ na decyzję władz szwajcarskich.

Wraz z początkiem 1941 roku sytuacja znalazła się w impasie, a decyzje w sprawie przyszłości 2 . DSP podejmowane były poza plecami dyplomacji polskiej, która od samego początku nie miała zresztą większego wpływu na ich ostateczny rezultat. W tej sytuacji nie pozostawało już faktycznie nic innego, jak tylko stanąć ściśle na gruncie obowiązującego prawa międzynarodowego. 7 stycznia 1941 roku Ładoś złożył w FDP specjalny aide-mémoire, w którym raz jeszcze przypomniał stanowisko swojego rządu w związku z formalno-prawnym statusem 2. DSP oraz zadeklarował, że jest gotowy do podpisania specjalnego porozumienia regulującego problem zwrotu kosztów pobytu internowanych żołnierzy na terytorium Szwajcarii ${ }^{27}$. Było to już

22 Depesza do Londynu nr 180 z 18.12.1940, AAN, Poselstwo RP w Bernie, sygn. 318.

23 Depesza z Londynu nr 145 z $18.12 .1940 \ldots$

24 Depesza z Londynu nr 156 z dn. 28.12.1940, AAN, Poselstwo RP w Bernie, sygn. 318.

25 Polish division in Switzerland [kopia brytyjskiej noty z 4 lipca 1940 r.], AFS, E2001D, 1000/1553/320; E. Bonjour, Geschichte der Schweizerischen Neutralität, VIII (Dokumente 19391945), Basel 1974, s. 114-115; Aide-mémoire [kopia brytyjskiego aide-mémoire z 15 stycznia 1941 r.], 1000/1553/320; Depesza z Londynu nr 115 z dnia 12.7.1941, AAN, Poselstwo RP w Bernie, sygn. 319.

26 Szerzej na ten temat zob.: E. Bonjour, Histoire..., t. VI, s. 285-352; N. Wyllie, Britain, Switzerland, and the Second World War, Oxford 2003, s. 121-163; La Suisse, le national-socialisme et la Seconde Guerre mondiale, Zürich 2002, s. 165-186.

27 [Kopia pisma A. Ładosia do Pierre'a Bonny z 7 stycznia 1941 r.], AFS, E 2001D, 1000/1553/320; S.E. Nahlik, Przesiane przez pamięć, t. II, Kraków 2002, s. 248-250. Wcześniej polski poseł złożył 
jednak posunięcie pozbawione jakiegokolwiek praktycznego znaczenia. Kilka dni później stało się jasne, że polscy żołnierze ostatecznie zostaną w Szwajcarii z powodu sprzeciwu Niemców, którzy obawiali się, iż wielu z nich będzie się starało przedostać do Wielkiej Brytanii w celu dalszego kontynuowania walki ${ }^{28} . \mathrm{Z}$ tego punktu widzenia ich dalszy pobyt na terytorium państwa neutralnego wydawał się dosyć dogodnym rozwiązaniem. O formalnym zakończeniu rokowań helwecka opinia publiczna została poinformowana 15 stycznia 1941 roku. Niemcy ostatecznie zgodzili się na repatriację żołnierzy francuskich, otrzymując jednak w zamian cały sprzęt bojowy, w tym także ten należący do 2 . DSP ${ }^{29}$. Spotkało się to oczywiście ze stanowczym sprzeciwem Polaków, a Ładoś zapowiedział złożenie w tej sprawie oficjalnego protestu $^{30}$. Postępowanie władz federalnych skłoniło również gen. Prugara-Ketlinga do przesłania listu protestacyjnego na ręce gen. Guisana ${ }^{31}$. Sprawa ta była zresztą dla Szwajcarów dosyć drażliwa, oczywiście nie z powodu łatwego do przewidzenia stanowiska rządu polskiego, lecz z obawy przed gwałtowną reakcją własnej opinii publicznej oraz zdecydowaną postawą władz brytyjskich ${ }^{32}$.

Oburzenie polskiej społeczności w Szwajcarii było niewątpliwie uzasadnione. Ładoś zdawał sobie jednak sprawę, że tak naprawdę udało się wyjść z zaistniałego kryzysu obronną ręką, a konieczność oddania broni stanowiła po prostu cenę, jaką należało zapłacić za możliwość pozostania na miejscu żołnierzy 2. DSP. Stąd też zaistniałą sytuację uznał po latach za kompromis, który należało po prostu zaakceptować ${ }^{33}$. Trudno się więc dziwić, że pomimo prezentowanego na zewnątrz „formalnego" oburzenia w jednej z depesz przesłanych do Londynu nie krył swojego zadowolenia, tym bardziej że podczas spotkania z Pilet-Golazem uzyskał od niego oficjalne oświadczenie o pozostaniu 2. DSP na terytorium szwajcarskim. Szef

w Federalnym Departamencie Politycznym pytanie o miesięczny koszt internowania polskich żołnierzy. Zob.: [Pismo Poselstwa RP w Bernie do Federalnego Departamentu Politycznego z 28 grudnia 1940 r.], AFS, E 2001D, 1000/1553/320.

28 E. Bonjour, Histoire..., s. 73.

${ }_{29}$ Ibidem, s. 82-83; [Kopia pisma z Ambasady Francuskiej w Bernie do M. Pilet-Golaza z 25 grudnia 1940 r.], AFS, E 2001D, 1000/1553/320.

${ }^{30}$ Telegram do Londynu nr 10 z 16.1.41, AAN, Poselstwo RPw Bernie, sygn. 325. Kopie dokumentów w tej sprawie, a w szczególności korespondencji z FDP zob. CAW, 2DSP, II. 50. 216, k. 2-24. W związku ze zwrotem uzbrojenia należącego do 2. DSP Poselstwo RP otrzymało oficjalne pismo wzywające je do zwrotu samochodu, który został wcześniej wypożyczony przez Federalny Komisariat Internowania i Hospitalizacji. Zob. [Pismo kpt. Serviena z Federalnego Komisariatu Internowania i Hospitalizacji do Stefana Ryniewicza z 19 lutego 1941 r.], AFS, E2001E, 1000/1571/40. Na podstawie lektury wspomnień Ładosia można wywnioskować, że na temat planów oddania Niemcom broni należącej do Polaków dowiedział się już znacznie wcześniej i próbował wpłynąć na zmianę tej decyzji podczas rozmów prowadzonych z Pilet-Golazem. Zob. A. Ładoś, Wspomnienia, t. III, s. 45-47.

31 Pismo gen. B. Prugara-Ketlinga do gen. H. Guisana z 16 stycznia 1941 r. (kopia), CAW, 2DSP, II. 50. 197, k. 61-63; E. B onj ou r, Histoire..., s. 88-90; S.E. Nahlik, op. cit., s. 250-251; P. Stau ffer, op. cit., s. 127-128; A. Blum, O broń i orly narodowe... Z Wilna przez Francję i Szwajcarię do Włoch, Pruszków 1997, s. 95-97.

32 Szerzej na ten temat zob. E. B onj ou r, Histoire..., s. 74-76, 79-83. Brytyjczycy faktycznie złożyli w tej sprawie formalny protest, nie odniósł on jednak żadnego skutku. Zob. E. B onj our, Geschichte der Schweizerischen Neutralität, VIII, s. 129-137.

33 A. Ładoś, Wspomnienia, t. III, s. 47-48. 
helweckiej dyplomacji zapewnił także swojego rozmówcę, że nie uczyni publicznego użytku z deklaracji władz w Vichy, które wyraziły gotowość przyjęcia z powrotem wszystkich Polaków zamieszkałych przed wojną we Francji. Oświadczenie to wywołało bowiem pewne zamieszanie wśród internowanych. Niektórzy z nich nie mogli po prostu zrozumieć, dlaczego odmawia im się prawa powrotu do domu ${ }^{34}$. W tym kontekście deklarację szefa helweckiej dyplomacji można rozumieć jako wyraz jego dobrej woli oraz zapowiedź, że w przyszłości będzie się stosował do poczynionych ustaleń w sprawie 2. DSP. Problem przekazanej Niemcom broni stał się jeszcze przedmiotem pewnych interpelacji ze strony Ładosia, sprawa była już jednak definitywnie zamknięta, a szef FDP thumaczył swojemu rozmówcy, że o stanowisku władz szwajcarskich przesądziła w rzeczywistości postawa francuskiego rządu ${ }^{35}$.

$\mathrm{Z}$ formalnego punktu widzenia sprawę można więc było uznać za zamkniętą. W rzeczywistości nie było to jednak wcale tak oczywiste, z czego Ładoś niewątpliwie zdawał sobie sprawę. Niepokój musiał przede wszystkim budzić fakt, że Szwajcarzy dosyć swobodnie interpretowali przepisy prawa międzynarodowego i to nie one uchroniły dywizję jako całość przed odesłaniem do Francji. Istniała więc realna obawa, że w bliższej lub dalszej przyszłości mogą się pojawić okoliczności, które raz jeszcze postawią ten problem na porządku dziennym. Zresztą w obozach w dalszym ciągu panowała nie najlepsza atmosfera. Niektórzy żołnierze byli niezadowoleni z powodu uniemożliwienia im powrotu do Francji, gdzie często pozostawili rodziny $^{36}$, powszechnie utrzymywała się również niepewność spowodowana obawą przed wydaniem bezpośrednio w ręce Niemców. Wyrazem tych nastrojów może być dosyć enigmatyczna treść jednej z depesz przesłanych do Londynu, w której Ładoś nie wykluczał konieczności zaopatrzenia wszystkich polskich żołnierzy w paszporty ${ }^{37}$. Najwyraźniej on także nie dowierzał Szwajcarom, o czym świadczy zresztą treść jego rozmowy z komisarzem internowania płk. Henrym, podczas której poruszył problem wspomnianego wcześniej niepokoju, dającego się wyczuć już od pewnego czasu wśród żołnierzy 2. DSP. Rozmówca polskiego dyplomaty oczywiście zdementował wszelkie pogłoski, uznając je za pozbawione wszelkich realnych podstaw ${ }^{38}$.

Czy deklaracje te można uznać za wiarygodne? Trudno udzielić jednoznacznej odpowiedzi na tak postawione pytanie. Oczywiście, uznając za bezzasadne wszelkie pogłoski dotyczące możliwości wydania internowanych władzom III Rzeszy, szwajcarski wojskowy prawdopodobnie nie mijał się z prawdą. Nie istnieją bowiem żadne dowody mogące świadczyć o tym, że helweckie władze brały pod uwagę zastosowanie aż tak radykalnych środków. Zresztą podobnym rozwiązaniem nie byli przecież zainteresowani sami Niemcy. A jednak zachowane źródła pokazują wyraźnie,

34 Telegram do Londynu nr $14 \mathrm{z}$ dnia 23.1.1941, AAN, Poselstwo RP w Bernie, sygn. 325;

E. Bonjour, Histoire..., s. 87-88.

35 Ibidem.

36 A. Vetulani, Poza plomieniami wojny. Internowani w Szwajcarii 1940-1945, Warszawa 1976, s. 78-79.

37 Telegram do Londynu nr 20 z 6.2.1941, AAN, Poselstwo RP w Bernie, sygn. 325.

38 Notice pour Monsieur le Conseiller fédéral Kobelt chef du Département Militaire Fédéral, AFS, J1.17, 1990/98/11. 
że porozumienie ze stycznia 1941 roku nie było przez Pilet-Golaza traktowane jako rozwiązanie ostateczne. Nie zrezygnował on bowiem z dążeń do pozbycia się żołnierzy 2. DSP z terytorium Szwajcarii, o czym świadczy jednoznacznie sprawozdanie z poufnej narady, która odbyła się 19 czerwca 1941 roku w siedzibie FDP ${ }^{39}$. Na podstawie treści tego dokumentu nie sposób jednak wywnioskować, w jaki sposób i na jakich warunkach szef helweckiej dyplomacji zamierzał wcielić swoje zamierzenia w życie. Tym bardziej że internowanie stawało się faktem, a polscy żołnierze byli coraz częściej wykorzystywani przy różnego rodzaju pracach, podczas gdy innym umożliwiono studia na szwajcarskich uczelniach ${ }^{40}$. Nie wiadomo, czy Ładoś wiedział o tych planach. Można jedynie przypuszczać, że mógł się ich domyślać. Przeczuwał zapewne także, że szef FDP prowadzi wobec niego podwójną grę.

Protokół ze wspomnianej wcześniej narady stanowi tak naprawdę jedyny źródłowy ślad świadczący o próbie pozbycia się polskiej dywizji już po zawarciu styczniowego porozumienia. Czy jest to tylko przypadek, czy też po 19 czerwca 1941 roku faktycznie pogodzono się z pobytem internowanych żołnierzy na terytorium Szwajcarii? Dylemat ten dałoby się ostatecznie rozstrzygnąć jedynie dzięki odkryciu nowych, nieznanych dotychczas dokumentów. Warto jednak zwrócić uwagę na dosyć zastanawiającą zbieżność dat. Otóż spotkanie w FDP odbyło się zaledwie trzy dni przed hitlerowską agresją na ZSRR, co Szwajcarzy odczuli przecież jako czynnik poważnie zmniejszający dotychczasowy nacisk na ich kraj ze strony Niemiec ${ }^{41}$. Można więc wysunąć hipotezę, że wydarzenie to zadecydowało ostatecznie o porzuceniu przez Pilet-Golaza planów pozbycia się 2. DSP. Warto bowiem pamiętać, że internowani żołnierze polscy poważnie obciążali hipotekę stosunków szwajcarsko-niemieckich, co stanowiło źródło wielu konfliktów. Była to dosyć paradoksalna sytuacja, ponieważ z jednej strony to właśnie stanowisko III Rzeszy zadecydowało o pozostaniu Polaków w Szwajcarii, z drugiej natomiast ich obecność drażniła niemieckie poselstwo w Bernie. Hitlerowcom nie podobały się przede wszystkim nasilające się ucieczki, co powodowało interwencje u władz szwajcarskich, a te z kolei zwracały się w tej sprawie do Ładosia ${ }^{42}$. Szczególne zamieszanie wywołało oświadczenie złożone przez gen. Prugara-Ketlinga podczas jego spotkania z gen. Guisanem, do którego doszło 22 kwietnia $1941 \mathrm{roku}^{43}$. Polski dowódca zadeklarował wówczas gotowość swojej dywizji do podjęcia walki u boku Szwajcarów na wypadek niemieckiego ataku na ich

39 Compte - rendu de la conference réunie par M. le Conseiller Fédéral Pilet-Golaz le 19 juin 1941, AFS, J1.17, 1990/98/11.

40 Literatura poświęcona tym aspektom pobytu żołnierzy polskich w Szwajcarii jest już bardzo obfita. Zob. m.in.: W. Drobny, Walka bez oręża. Polskie obozy uniwersyteckie dla internowanych w Szwajcarii w latach 1940-1946, Warszawa-Poznań 1985; A. Vetulani, op. cit.; T. Zaniewska, Szkolnictwo polskie w Szwajcarii w czasie II wojny światowej, „Prace Komisji Historii Nauki Polskiej Akademii Umiejętności” 2004, t. VI, s. 95-117.

${ }^{41}$ A. Lasserre, La Suisse des années sombres. Courants d'opinion pendant la Deuxième Guerre mundiale 1939-1945, Lausanne 1989, s. 183-186.

42 A. Ładoś, Wspomnienia, t. III, s. 29-30.

43 Rozmowa odbyła się niewątpliwie $\mathrm{z}$ inicjatywy samego gen. Guisana. Zob. [Pismo gen. Guisana do szefa Federalnego Departamentu Wojskowego Karla Kobelta z 22 maja 1941 r.], AFS, J1. 17, 1990/98/11. Zob. także: Z. Prugar-Ketling, Generat Bronisław Prugar-Ketling. Wspomnienia syna, 
kraj. Treść tej wypowiedzi szybko dotarła nie tylko do FDP, wywołując gwałtowną reakcję Pilet-Golaza ${ }^{44}$, lecz także do niemieckiego przedstawicielstwa w Bernie. $\mathrm{Na}$ reakcję posła Köchera w tej sprawie nie trzeba było długo czekać. Fakt ten skłonił szefa helweckiej dyplomacji do wystosowania uspokajającej noty ${ }^{45}$. Ostatecznie wydarzenie to okazało się zaledwie epizodem, który mógł jednak poważnie zaciążyć na ówczesnych stosunkach polsko-szwajcarskich. A jednym z kluczowych ich aspektów było oczywiście zagadnienie 2. DSP, która zajmowała określone miejsce w planach Naczelnego Wodza jako zwarta jednostka bojowa, co najwyraźniej kolidowało ze wspomnianymi wcześniej koncepcjami Pilet-Golaza. W zagadnienie to wpisuje się problem z nominacją, a następnie z działalnością polskiego oficera pełniącego obowiązki attaché wojskowego w Bernie.

Dotychczas stanowisko to zajmował formalnie były attaché wojskowy w Berlinie płk. Antoni Szymański, który przebywał wówczas w charakterze więźnia na terenie $\mathrm{ZSRR}^{46}$. Obecnie wraz z przekroczeniem granicy przez żołnierzy 2. DSP zaczęto zastanawiać się nad zastąpieniem go przez innego oficera, który mógłby rozpocząc normalną pracę w Bernie ${ }^{47}$. Co ciekawe, z podobną propozycją miała rzekomo wystąpić strona szwajcarska, o czym Ładoś poinformował swoich zwierzchników w lipcu 1940 roku. Początkowo skłaniał się on oczywiście w kierunku jej akceptacji, sugerując powierzenie tej funkcji Szczęsnemu Chojnackiemu ${ }^{48}$. Wkrótce okazało się jednak, że informacje przekazane przez posła były błędne, a władze federalne wcale nie życzą sobie powiększenia obsady polskiej placówki. Trudno obecnie stwierdzić, w jaki sposób doszło do tego nieporozumienia, w każdym razie dwa tygodnie później Ładoś ostrzegł swoich zwierzchników, że w obecnych warunkach przeprowadzenie podobnej nominacji może się okazać niezwykle trudne. W tym celu należałoby najpierw odwołać Szymańskiego, co w związku z prawdopodobną odmową uznania jego następcy mogło pozbawić stronę polską jakiegokolwiek attaché wojskowego w Bernie. Poseł zasugerował jednak zastosowanie w tej sprawie prawnego wybiegu, polegającego na formalnej nominacji Bronisława Noëla, przewidzianego na następcę

Warszawa 2006, s. 173-175; J. S molińs ki, Polacy internowani w Szwajcarii (1940-1945). Dokumenty prawno-organizacyjne, wykaz internowanych, Warszawa 2003, s. 10.

44 Notice pour Monsieur le Ministre Bonna. Copie, AFS, J1.17, 1990/98/11; [Pismo gen. Guisana do Pilet-Golaza z 22 maja 1941 r.], J1.17, 1990/98/11; [Notatka z rozmowy pomiędzy A. Ładosiem a M. Pilet-Golazem z 28 maja 1941 r.], AFS, J1.17, 1990/98/11.

45 Notice pour Monsieur le Ministre Bonna...; [Kopia pisma Niemieckiego Poselstwa nr 2648 dla Federalnego Departamentu Politycznego z 16 czerwca 1941 r.], AFS, J1.17, 1990/98/11; Conférence avec le Ministre d'Allemagne à 11 heures 30 [27 juin 1941], AFS, E2809, 1000/723/2; E. Bonjour, Histoire..., s. 297-298.

46 G. Lukomski, Generat brygady Antoni Szymański (1894-1973). Wielkopolanin - żotnierz i dyplomata, Pruszków-Warszawa-Londyn 2006, s. 43-45.

47 W oficjalnej historii 2. DSP problem ten został określony w następujący sposób: „Brak legalnego reprezentanta wojska przy poselstwie pozbawiał internowaną dywizję rzecznika jej spraw na szczeblu dyplomatycznym". Zob. Nasza droga. Dzieje 2-ej Dywizji Strzelców Pieszych. Francja-Szwajcaria 1939-1945, Londyn 1960, s. 239.

48 [Telegram Aleksandra Ładosia nr 54 do Ministerstwa Spraw Zagranicznych z 13 lipca 1940 r.], AAN, IH, MSZ, Folder 3, sygn. 212. 
Szymańskiego, w charakterze jego pomocnika ${ }^{49}$. Propozycja ta spotkała się z akceptacją gen. Sikorskiego ${ }^{50}$. Początkowo mogło się więc wydawać, że wszystko ułoży się zgodnie z przewidywaniami, na co zdawały się zresztą wskazywać wyniki pierwszych sondaży przeprowadzonych na miejscu przez Ładosia. Doniesienia wysyłane przez niego do Londynu były przepełnione optymizmem ${ }^{51}$, a 11 sierpnia poseł otrzymał polecenie zgłoszenia faktu przybycia polskiego oficera w charakterze zastępcy dotychczasowego attaché wojskowego ${ }^{52}$.

Tyle można się w tej sprawie dowiedzieć z polskich źródeł dyplomatycznych. Dokumenty szwajcarskie pokazują jednak to zagadnienie w odmiennym świetle, rzucając jednocześnie cień na wiarygodność informacji przesyłanych przez Ładosia do Londynu. Okazuje się bowiem, że polski poseł jeszcze przed wysłaniem depeszy ostrzegającej przed próbą nominacji nowego attaché wojskowego odbył w tej sprawie rozmowę z Bonną, który jednoznacznie podkreślił, że jego kraj nie zgodzi się na powiększenie personelu Poselstwa RP. Podobne stanowisko spotkało się oczywiście z akceptacją Pilet-Golaza, o czym poinformowano Ładosia. Co więcej, rozmowa prowadzona $\mathrm{w}$ języku francuskim dotyczyła ewidentnie zastępcy attaché wojskowego (attaché militaire adjoint), nie może więc być w tym przypadku mowy o żadnej pomyłce. Jedyną wątpliwość budzi fakt, że notatka zawierająca informacje o tej rozmowie została sporządzona dopiero 26 maja $1941 \mathrm{roku}^{53}$. Była ona jednak przeznaczona do użytku wewnętrznego, nie ma więc żadnych powodów, aby kwestionować jej treść. Nie chodziło zresztą w tym przypadku o brak akceptacji dla takiej lub innej osoby, lecz o samą zasadę. Wystarczy bowiem przypomnieć problemy przy zmianie na stanowisku posła RP w Bernie ${ }^{54}$, aby zrozumieć, że Szwajcarzy akceptowali co prawda istnienie Poselstwa RP, nie godzili się jednak na żadne personalne roszady z obawy przed reakcją ze strony Niemców. Nasuwa się więc pytanie, dlaczego Ładoś ukrył przed Zaleskim faktyczny stan rzeczy i zaproponował przeprowadzenie nominacji Noëla w charakterze zastępcy Szymańskiego, a następnie utwierdził go w przekonaniu, że podobne rozwiązanie nie napotka w Bernie na żadne trudności ze strony władz federalnych? Na tak postawione pytanie nie sposób udzielić jednoznacznej odpowiedzi. Być może polski poseł liczył na to, że opinia wyrażona przez Bonnę zostanie następnie podważona przez Pilet-Golaza, co umożliwi nominację Noëla zgodnie z postulatami wysuwanymi przez stronę polską? Jest to mało prawdopodobne, ponieważ Ładoś zbyt dobrze orientował się w mechanizmach funkcjonowania helweckiej dyplomacji. A może postanowił działać w tej sprawie metodą faktów do-

49 [Telegram Aleksandra Ładosia nr 80 do Ministerstwa Spraw Zagranicznych z 28 lipca 1940 r.], AAN, IH, MSZ, Folder 3, sygn. 212.

50 Depesza z Londynu nr 34 z 3.8.1940, AAN, Poselstwo RP w Bernie, sygn. 318.

51 Depesza do Londynu nr 83 z 6.8.1940, AAN, Poselstwo RP w Bernie, sygn. 318.

52 Depesza z Londynu nr 36 z 11.8.1940, AAN, Poselstwo RP w Bernie, sygn. 318.

53 Notice [26.V.1941], AFS, E2001D, 1000/1552/111.

54 Szerzej zob.: E. Bonjour, Histoire..., t. IV, Neuchâtel 1971, s. 291-296; A. Kołodziejczyk, Aleksander Ładoś (1891-1963) - działacz niepodległościowy, dyplomata, ludowiec, „Rocznik Dziejów Ruchu Ludowego" 2000, nr 31, s. 259; H. Batowski, Z dziejów dyplomacji polskiej na obczyźnie (wrzesień 1939 - lipiec 1941), Kraków-Wrocław 1984, s. 88-90; P. Dubner, „Burzliwe” wiosna i lato 1940 r. w polsko-szwajcarskich stosunkach dyplomatycznych, „Glankopis” 2018, nr 35, s. 209-224. 
konanych, licząc na to, że istnieją duże szanse przeprowadzenia podobnej nominacji nawet wbrew woli Szwajcarów? Jeżeli tak, to trzeba przyznać, że się nie mylił i udało mu się osiągnąć zamierzony cel.

Polski MSZ, przekonany o załatwieniu na miejscu całej sprawy przez Ładosia, postanowił uzyskać dla Noëla wizę wjazdową do Szwajcarii, zwracając się w tej sprawie do Poselstwa tego kraju w Londynie. Po załatwieniu niezbędnych formalności polski oficer pojawił się na początku września w Bernie, wzbudzając konsternację urzędników FDP ${ }^{55}$. Początkowo Szwajcarzy nalegali na jego natychmiastowy wyjazd, Ładoś przekonał ich jednak, że swoją wizę otrzymał on jeszcze przed wyrażeniem negatywnej opinii przez Pilet-Golaza, a ponadto powrót Noëla do Anglii mógłby okazać się niezwykle trudny do wykonania ${ }^{56}$. Ostatecznie Noël otrzymał zgodę na pozostanie w Szwajcarii, nie mógł jednak sprawować żadnych oficjalnych funkcji, a tym bardziej kontaktować się z czynnikami wojskowymi, zwłaszcza z internowanymi żołnierzami 2. DSP. Mógł natomiast doradzać nieoficjalnie szefowi Poselstwa w kwestiach odnoszących się do zagadnień militarnych ${ }^{57}$.

Ładosiowi udało się więc doprowadzić do pozostania Noëla w Szwajcarii, co miało niewątpliwie pewne znaczenie $\mathrm{z}$ punktu widzenia polskich interesów $\mathrm{w}$ tym kraju. Warto jednak się zastanowić, czy sprzeciw gospodarzy wynikał jedynie z obawy przed reakcją ze strony Niemców, czy też nie miał on także związku z planami odesłania żołnierzy 2. DSP z powrotem do Francji. Jak wiadomo, polskie władze dążyły do utrzymania zwartego charakteru 2. DSP, w czym mogła niewątpliwie pomóc obecność na miejscu attaché wojskowego, z czego Szwajcarzy doskonale zdawali sobie sprawę. Trudno się więc dziwić, że zabronili mu pełnić rolę, jak to określono, „pośrednika pomiędzy Poselstwem RP a internowanymi" ${ }^{58}$. Musiało to w sposób nieunikniony prowadzić do dalszych konfliktów, trudno było bowiem oczekiwać od Noëla, że zastosuje się on do życzeń FDP - brak możliwości kontaktu z polskimi żołnierzami w zasadzie pozbawiał jego misję większego sensu. W styczniu 1941 roku Ładoś poinformował o tych problemach Londyn, pisząc wprost, że Noël jest przez Szwajcarów jedynie ,tolerowany” i nie posiada ,ani kontaktu z nimi, ani z obozami

55 Notice [26. V. 1941] ...

56 Ibidem. Co ciekawe, polski oficer przywiózł ze sobą specjalne przesłanie gen. Sikorskiego adresowane do gen. Guisana.

57 Ibidem. Postępowanie posła szwajcarskiego w Londynie $\mathrm{w}$ tej sprawie spotkało się z surową reprymendą ze strony Departamentu Politycznego. Zob.: [Kopia telegramu do Poselstwa Szwajcarskiego w Londynie z 10 września 1940 r.], AFS, E2001D, 1000/1552/111. Zgodnie $\mathrm{z}$ informacją zawartą w specjalnej, kilkustronicowej notatce poświęconej sytuacji polskich placówek dyplomatycznych w poszczególnych państwach, Noël nie został mianowany attaché wojskowym, lecz jego zastępcą, z uwagi na „obecną delikatną sytuację”. Zob. Notatka w sprawie sytuacji na Placówkach RP za granicą, wytworzonej działalnością „misji” i „delegatów”, w krajach neutralnych, AAN, IH, MSZ, Folder 9, sygn. 301.

58 Notice [26.V.1941]... Niewykluczone, że z tych samych powodów Szwajcarzy nie chcieli zgodzić się na przyznane Halinie Szymańskiej jakiejkolwiek oficjalnej funkcji w związku z jej zaangażowaniem w pomoc dla żołnierzy 2. DSP. Zob. Depesza do Londynu nr 143 z 24.10.1940, AAN, Poselstwo RP w Bernie, sygn. 318. Szerzej na temat działalności Szymańskiej w Szwajcarii na rzecz internowanych zob. P. Kanafocka, G. Łukomski, Dama polskiego wywiadu. Halina Maria Szymańska 1906-1989, Warszawa 2015, s. 87-91. 
internowanych" 59 . Pilet-Golaz zarzucił między innymi polskiemu oficerowi narażenie na szwank szwajcarskiej neutralności ${ }^{60}$, co skłoniło go nawet do wysunięcia wobec polskiego posła żądania natychmiastowego wyjazdu Noëla ${ }^{61}$.

Głównym powodem antagonizmu na linii Poselstwo-FDP były jednak kierowane pod adresem polskiego attaché wojskowego podejrzenia o pomoc w ucieczkach podejmowanych przez internowanych żołnierzy, dla których miał nawet pozyskiwać dokumenty, korzystając $\mathrm{w}$ tym celu między innymi z pomocy bułgarskiego Poselstwa $^{62}$. Jest to dosyć zastanawiające, podobne postępowanie oznaczałoby bowiem działanie wbrew wyraźnemu rozkazowi Naczelnego Wodza ${ }^{63}$. Co ciekawe, pewne relacje pamiętnikarskie potwierdzają istnienie zorganizowanej akcji mającej na celu wydostanie z internowania jak największej liczby polskich żołnierzy. Sądząc po ich treści, mogli w nią być zamieszani niektórzy wyżsi oficerowie dywizji ${ }^{64}$. Istniejący materiał źródłowy pokazuje jednak, że w tym przypadku Szwajcarzy raczej mylili się w ocenie Noëla, który otrzymał od dowódcy 2. DSP wyraźne polecenie przeciwstawienia się narastającej fali ucieczek ${ }^{65}$. Strona polska przywiązywała niewątpliwie dużą wagę do prowadzonej przez niego działalności, o czym świadczy między innymi depesza Naczelnego Wodza adresowana do Ładosia, w której podkreślił on konieczność utrzymania na miejscu polskiego attaché wojskowego, „choćby w dotychczasowym nieoficjalnym charakterze" ${ }^{" 6}$. Oczywiście można się domyślać, że Noël prowadził na miejscu działalność wywiadowczą, o czym zdaje się świadczyć fakt, iż jego praca bardzo interesowała Anglików, którzy udzielali mu wsparcia finansowego ${ }^{67}$. Można jednak z dużym prawdopodobieństwem przypuszczać, że wbrew formalnemu zakazowi starał się on utrzymywać nieformalne kontakty z internowanymi żołnierzami 2. DSP, prowadząc wśród nich działalność zmierzającą do utrzymania

59 Depesza z Berna nr 7 z dnia 14.1.1941, AAN, Poselstwo RP w Bernie, sygn. 325.

60 W tym przypadku chodziło o deklarację złożoną przez niego w imieniu Naczelnego Wodza, w której znalazła się propozycja wykorzystania polskiej dywizji na wypadek ewentualnego niemieckiego ataku na Szwajcarię. Zob. Declaration, AFS, J1.17, 1990/98/11.

61 Depesza z Berna nr 105 z dnia 9.7.1941, AAN, Poselstwo RP w Bernie, sygn. 325.

62 Notice [6 XI 1940], AFS, E2001D, 1000/1552/111. Przynajmniej w jednym przypadku o udzielanie podobnej pomocy został również posądzony Ładoś. Zob.: [Pismo Pilet-Golaza do Ładosia z 5 maja 1942 r.], AFS, E 2809, 1000/723/3; Notice pour Monsieur le Ministre Bonna [4 maja 1942], AFS, E 2809, 1000/723/3; Notice pour Monsieur le Ministre Bonna [19 kwietnia 1942], AFS, E 2809, 1000/723/3; [Pismo A. Ładosia do M. Pilet-Golaza z 24 marca 1942 r.], AFS, E 2809, 1000/723/3.

63 Szerzej na ten temat zob. A. Vetulani, op. cit., s. 79-82.

64 R. Jasińs ki, Wrzesień pod Alpami, Warszawa 1974, s. 145-183; M.Z. Rygor-Słowikowski, W tajnej stużbie. Jak polski wywiad dat aliantom zwycięstwo w Afryce Pólnocnej, Poznań 2011, s. 72. Niewątpliwie generał Prugar-Ketling dostrzegał nastroje panujące wśród oficerów 2. DSP, z których pewna część zamierzała nielegalnie opuścić terytorium Szwajcarii, co było przecież niezgodne z wcześniejszym rozkazem gen. Sikorskiego. Zob. Pismo mjr. dypl. Filipkowskiego do ppłk. dypl. Maliszewskiego z 19.IV.1941 r., CAW, 2DSP, II. 50. 197, k. 325.

65 Pismo gen. Prugara-Ketlinga do ppłk. Bronisława Noëla z 13 maja 1941 r., CAW, 2DSP, II. 50. 203, k. 57.

66 Depesza z Londynu nr 127 z dnia 19.7.1941, AAN, Poselstwo RP w Bernie, sygn. 319.

${ }^{67}$ W lipcu 1941 r. na jego ręce została np. przekazana suma 10 tys. funtów. Zob. Depesza z Londynu nr 132 z dnia 26.7.1941, AAN, Poselstwo RP w Bernie, sygn. 319. 
zwartego charakteru jednostki. Prowadziło to do poważnych napięć w stosunkach ze stroną szwajcarską, narażając go nawet na wspomniane wcześniej zarzuty o podsycanie ucieczek z obozów. Postawione przed nim zadanie z pewnością nie należało do łatwych, a działania prowadzone na przekór władzom helweckim stale komplikowały jego położenie, ostatecznie przyczyniając się do opuszczenia przez niego terytorium Szwajcarii ${ }^{68}$.

Ostatecznie Polacy pozostali w Szwajcarii aż do 1945 roku, co z początku wcale nie było takie oczywiste $\mathrm{z}$ uwagi na fakt, że ich dalsze losy ważyły się $\mathrm{w}$ zasadzie przez okres pierwszych 12 miesięcy, które upłynęły od momentu internowania. $Z$ perspektywy lat sami żołnierze nie kryli słów uznania dla postawy społeczeństwa szwajcarskiego. Można się o tym przekonać między innymi na podstawie lektury jednego $\mathrm{z}$ fragmentów historii 2. DSP, opublikowanej wiele lat po zakończeniu wojny: „Przez całe pięć lat [...] byliśmy otoczeni sympatią, sentymentem i przychylnością całego społeczeństwa. Otwarto przed naszymi żołnierzami nie tylko gościnne podwoje swoich domów, ale i serca" ${ }^{69}$. Dla wielu z nich nie był to zresztą czas stracony, o czym świadczy niewątpliwie ówczesna aktywność zawodowa i kulturalna wielu polskich internowanych ${ }^{70}$. Przymusowy pobyt pod Alpami przedłużył się jednak wbrew woli żołnierzy wywodzących się z przedwojennej emigracji, z których duża część chciała powrócić do domu podobnie jak ich francuscy koledzy. Tak też widział ten problem poseł RP w Bernie. Jego zdaniem należało pozwolić na wyjazd osobom niezadowolonym, o niskim morale, umożliwiając pozostanie na miejscu tym, którzy w przyszłości będą jeszcze mogli powrócić do czynnej służby wojskowej. W tym właśnie duchu starał się oddziaływać na władze szwajcarskie. Nie liczyły się one jednak z jego zdaniem, dążąc po prostu do pozbycia się całej internowanej dywizji. Taktyki zaproponowanej przez Ładosia nie akceptował również Sikorski, stojąc twardo na gruncie nienaruszalności polskich praw. Analizując ten spór, nie sposób oprzeć się wrażeniu, że w pewnym sensie stanowił on przedsmak tego, co miało nastąpić w ostatnim okresie wojny, gdy polskie uchodźstwo niepodległościowe podzieliło się na polityków godzących się na dyktat jałtański w imię zachowania

68 Nastąpiło to ostatecznie 7 maja 1942 r., po przekazaniu obowiązków mjr. Chojnackiemu. Zob. R. Majzner, Attachaty wojskowe Drugiej Rzeczypospolitej 1919-1945. Strukturalno-organizacyjne aspekty funkcjonowania, Częstochowa 2011, s. 418. Autorzy historii 2. DSP stwierdzili po latach, iż Noël „miał b. trudną pracę i z interwencją jego nie liczono się w tym stopniu, co np. z interwencją attaché wojskowego niemieckiego". Zob. Nasza droga..., s. 239.

${ }^{69}$ Nasza droga..., s. 237.

70 Różnorodna działalność polskich żołnierzy w Szwajcarii w okresie ich przymusowego internowania $\mathrm{w}$ dalszym ciągu budzi duże zainteresowanie, o czym świadczy stosunkowo duża ilość prac poświęconych tej tematyce. Zob. np.: Żolnierze polscy internowani w Szwajcarii (1940-1945). Die in der Schweiz Internierten Polnischen Soldaten (1940-1945), pod red. J. Smolińskiego, Warszawa 2010; Helvétie, terre d'accueil...: espoirs et vie quotidienne des internés polonais en Suisse 1940-1946 en images $=$ Helvetien, Aufnahmeland...: Hoffnungen und tägliches Leben der polnischen Internierten in der Schweiz 1940-1946, Fribourg 2000; S. Piekarski, Muzy za drutami. Twórczość sceniczna żolnierzy polskich w obozach internowania w latach 1939-1947, t. I-II, Warszawa 2005; W. D robny, Polskie obozy uniwersyteckie dla internowanych w Szwajcarii w latach 1940-1945, Warszawa-Poznań 1985; G. Majka, Praca dla Szwajcarii, nauka dla Polski. 2. Dywizja Strzelców Pieszych w Szwajcarii, Warszawa 2015. 
resztek suwerenności oraz na „niezłomnych”, odrzucających myśl o jakimkolwiek kompromisie. Biorąc pod uwagę opisane wcześniej wydarzenia, trudno się dziwić, że Ładoś jako zwolennik Stanisława Mikołajczyka znalazł się w pierwszej z wymienionych grup, wchodząc w niemal otwarty konflikt $\mathrm{z}$ Adamem Tarnowskim, ministrem spraw zagranicznych w rządzie Tomasza Arciszewskiego ${ }^{71}$. Niestety, podobnie jak w przypadku zabiegów o pozostawienie 2. DSP w Szwajcarii, decyzje dotyczące żywotnych interesów Polski zapadały już bez jej udziału.

\section{BIBLIOGRAFIA}

\section{Źródła archiwalne}

Archives Fédérales Suisses

E 2001D (sygn. 1000/1553/320; 1000/1552/111)

E 2001E (sygn. 1000/1571/40)

E 2809 (sygn. 1000/723/2; 1000/723/3)

J1.17 (sygn. 1990/98/11)

Archiwum Akt Nowych

Poselstwo RP w Bernie (sygn. 318; 319; 325)

Instytut Hoovera, MSZ (sygn. 212; 301)

Centralne Archiwum Wojskowe

A. Ładoś, Wspomnienia, t. III (sygn. IX. 1. 2. 20).

2DSP (sygn. II. 50. 197; II. 50. 203; II. 50. 216)

\section{Dokumenty publikowane}

Bonjour E., Geschichte der Schweizerischen Neutralität, VIII (Dokumente 1939-1945), Basel 1974.

\section{Pamiętniki, wspomnienia}

Blum A., O broń i orty narodowe... Z Wilna przez Francję i Szwajcarię do Włoch, Pruszków 1997.

Jasiński R., Wrzesień pod Alpami, Warszawa 1974.

Nahlik E., Przesiane przez pamięć, t. II, Kraków 2002.

71 A. Kołodziejczyk, op. cit., s. 261-262. 
Prugar-Ketling Z., Generał Bronisław Prugar-Ketling. Wspomnienia syna, Warszawa 2006.

Rygor-Słowikowski M.Z., W tajnej stużbie. Jak polski wywiad dat aliantom zwycięstwo w Afryce Pótnocnej, Poznań 2011.

\section{Opracowania}

Batowski H., Z dziejów dyplomacji polskiej na obczyźnie (wrzesień 1939 - lipiec 1941), Kraków-Wrocław 1984.

Bonjour E., Histoire de la neutralité suisse pendant la Seconde Guerre mondiale, t. IV, Neuchâtel 1971.

Bonjour E., Histoire de la neutralité suisse pendant la Seconde Guerre mondiale, t. VI, Neuchâtel 1971.

Drobny W., Walka bez oręża. Polskie obozy uniwersyteckie dla internowanych w Szwajcarii w latach 1940-1946, Warszawa-Poznań 1985.

Dubicki T., Wojsko Polskie w Rumunii w latach 1939-1941, Warszawa 1994.

Dubner P., „Burzliwe” wiosna i lato 1940 r. w polsko-szwajcarskich stosunkach dyplomatycznych, „Glankopis” 2018, nr 35.

Helvétie, terre d'accueil...: espoirs et vie quotidienne des internés polonais en Suisse 1940 1946 en images $=$ Helvetien, Aufnahmeland...: Hoffnungen und tägliches Leben der polnischen Internierten in der Schweiz 1940-1946, Fribourg 2000.

Kanafocka P., Łukomski G., Dama polskiego wywiadu. Halina Maria Szymańska 19061989, Warszawa 2015.

Kołodziejczyk A., Aleksander Ładoś (1891-1963) - działacz niepodległościowy, dyplomata, ludowiec, „Rocznik Dziejów Ruchu Ludowego” 2000, nr 31.

Lasserre A., La Suisse des années sombres. Courants d'opinion pendant la Deuxième Guerre mundiale 1939-1945, Lausanne 1989.

La Suisse, le national-socialisme et la Seconde Guerre mondiale, Zürich 2002.

Łukomski G., Generał brygady Antoni Szymański (1894-1973). Wielkopolanin - żolnierz i dyplomata, Pruszków-Warszawa-Londyn 2006.

Majka G., Praca dla Szwajcarii, nauka dla Polski. 2. Dywizja Strzelców Pieszych w Szwajcarii, Warszawa 2015.

Majzner R., Attachaty wojskowe Drugiej Rzeczypospolitej 1919-1945. Strukturalno-organizacyjne aspekty funkcjonowania, Częstochowa 2011.

Matyja M., Internowanie polskiej 2. Dywizji Strzelców Pieszych w Szwajcarii w latach 1940-1945 na podstawie V konwencji haskiej z 1907 roku, Brzezia Łąka 2013.

Nasza droga. Dzieje 2-ej Dywizji Strzelców Pieszych. Francja-Szwajcaria 1939-1945, Londyn 1960.

Piekarski S., Muzy za drutami. Twórczość sceniczna żołnierzy polskich w obozach internowania w latach 1939-1947, t. I-II, Warszawa 2005.

Smoliński J., 2. Dywizja Strzelców Pieszych (Francja - Szwajcaria), Warszawa 1992.

Smoliński J., Polacy internowani w Szwajcarii (1940-1945). Dokumenty prawno-organizacyjne, wykaz internowanych, Warszawa 2003.

Stauffer P., Polacy - Żydzi - Szwajcarzy, Warszawa 2008.

Vetulani A., Poza płomieniami wojny. Internowani w Szwajcarii 1940-1945, Warszawa 1976. 
Wyllie N., Britain, Switzerland, and the Second World War, Oxford 2003.

Wyrwa T., Odbudowa władz Rzeczypospolitej w Paryżu i Angers wrzesień 1939 - czerwiec 1940 [w:] Władze RP na obczyźnie podczas II wojny światowej 1939-1945, red. Z. Błażyński, Londyn 1994.

Zaniewska T., Szkolnictwo polskie w Szwajcarii w czasie II wojny światowej, „Prace Komisji Historii Nauki Polskiej Akademii Umiejętności” 2004, t. VI.

Zuziak J., Wojsko Polskie we Francji 1939-1940. Organizacja $i$ działania bojowe, Warszawa 2013.

Żotnierze polscy internowani w Szwajcarii (1940-1945). Die in der Schweiz Internierten Polnischen Soldaten (1940-1945), pod red. J. Smolińskiego, Warszawa 2010. 